\title{
Usability Testing Process With People With DOWN SYNDROME INTREACTING WITH MOBILE Applications: A Literature REVieW
}

\author{
Doris Cáliz ${ }^{1}$, Loic Martinez ${ }^{1}$, Xavier Alaman ${ }^{2}$, Carlos Teran $^{3}$ and, Richart Caliz ${ }^{3}$. \\ 1 Department ETSIINF, DLSIIS, Madrid Polytechnic University, Campus de \\ Montegancedo 28660 , Boadilla del Monte , Madrid, Spain \\ ${ }^{2}$ Department of Computer Engineering, Autonomous University, Madrid, C/ Francisco \\ Tomás y Valiente, 11. 28049, Madrid, Spain. \\ ${ }^{3}$ Department of Computer Sciences FIS Group, National Polytechnic University, Ladrón \\ de Guevara E11-25 y Andalucía Quito, Ecuador
}

\begin{abstract}
We present a review of research related to the usability testing of mobile applications including participants with Down syndrome. The purpose is to identify good usability testing practices and possible guidelines for this process when participants are people with this cognitive disability. These practices and guidelines should account for their specific impairments. We applied document analysis techniques to searches of scientific databases. The results were filtered considering how well they matched the research topic. We processed and reported the classified and summarized results. The main findings of this literature review is that mobile applications usability testing including people with Down syndrome is an issue that has not be comprehensively investigated. While there is some related research, this is incomplete, and there is no single proposal that takes on board all the issues that could be taken into account. Consequently, we propose to develop guidelines on the usability testing process involving participants with Down syndrome.
\end{abstract}

\section{KEYWORDS}

Usability Testing, Mobile Applications, Cognitive Disability, Down Syndrome, Human Computer Interaction (HCI), Mobile Devices.

\section{INTRODUCTION}

Usability is a quality attribute of interactive systems defined by five attributes: learnability, efficiency, memorability, errors and satisfaction (Nielsen and Kaufmann). In ISO 9241-11 (Abran et al.), the International Organization for Standardizations (ISO) bases usability on three quality attributes: effectiveness, efficiency and satisfaction. Usability is one of the key qualities of a product or system. Systems whose usability is good are easy to learn, efficient, not prone to errors and generate user satisfaction (Nielsen and Kaufmann), (Abran et al.).This paper focuses on one particular cognitive disability: Down syndrome (DS). Down syndrome is a genetic disorder with a worldwide incidence close to one in every 700 births $(15 / 10,000)$, but the risk varies with the mother's age. In 2010 there were approximately 34,000 people with DS in Spain. People with DS have impaired cognitive processing, language learning and physical abilities, as well as different personal and social characteristics (Yussof and Badioze Zaman). 
If a system is to provide good usability for people with cognitive disabilities, usability testing should be performed by participants with such disabilities. This will necessarily have an impact on how the usability testing is performed.

This paper focuses on one particular cognitive disability: Down syndrome (DS). Down syndrome is a genetic disorder with a worldwide incidence close to one in every 700 births $(15 / 10,000)$, but the risk varies with the mother's age. In 2010 there were approximately 34,000 people with DS in Spain. Most people with DS have a mild to moderate intellectual disability and an intelligence quotient (IQ) within the range of 40 to 70 . Generally, people with DS find it easier to understand what other people say than to verbally express their own thoughts [1] People with DS have impaired cognitive processing, language learning and physical abilities, as well as different personal and social characteristics[2].

A usability testing methodology suitable for participants including people with DS needs to be well designed [3]. Interaction evaluation methods based on inspection and heuristics are unable to meet the needs of this population group, as they do not engage the end users and are unable to predict the usability of the systems developed for them [4]. This literature review sets out to ascertain the state of the art of usability testing practice when participants have DS. The article is structured as follows. First it describes the nine usability testing process steps. It then describes the literature review process, including the applied methodology, searches and filters.

\section{USABILITY TESTING PROCESS}

A user-centred design process is applied to build products and systems with a satisfactory level of usability [5]. As part of this process, planning, context of use analysis, interactive system design and evaluation tasks are carried out iteratively. A key step is usability evaluation. There are several methods for evaluating how usable a product or system is: heuristic or guideline evaluation, usability testing and follow-up studies of installed systems [6]. The most common method is usability testing, which involves testing prototypes with real users [7]. Participating users are set a number of tasks that they have to perform using a prototype or a full system. Data on the effectiveness, efficiency and satisfaction of users are collected during testing. Generally, the usability process is divided into the following steps: 1.Recruit participants , 2. Establish the tasks, 3.Write the instructions, 4.Define the test plan, 5.Run the pilot test, 6. Refine the test plan , 7.Run the test session, 8.Analyse the collected objective, 9.Report results. The literature review process described in Section 3 focused on identifying papers that report a usability test with people with Down syndrome and on retrieving the key information that they provide on each of these nine steps

\section{LITERATURE REVIEW PROCESS}

We applied a review and document analysis (RAD) methodology with two protocols: one for searching for sources of information and the other for inspecting the sources of information [8]. Table 1 shows the search protocol and Table 2 illustrates the document analysis protocol 
International Journal of Computer Science \& Information Technology (IJCSIT) Vol 8, No 3, June 2016

Table 1: Information source search protocol

\begin{tabular}{|c|c|c|}
\hline \multicolumn{3}{|c|}{ Information source search protocol } \\
\hline Language: & \multicolumn{2}{|c|}{ Spanish and English } \\
\hline Period: & \multicolumn{2}{|l|}{2008 to 2014} \\
\hline \multirow[t]{2}{*}{ Term } & Individual & $\begin{array}{l}\text { Usability, evaluation, down syndrome, cognitive disabilities, hci, human } \\
\text { computer interaction }\end{array}$ \\
\hline & Combinations & $\begin{array}{l}\text { Search 1: USABILITY EVALUATION DOWN SYNDROME } \\
\text { Search 2: COGNITIVE DISABILITIES USABILITY }\end{array}$ \\
\hline Information resources & \multicolumn{2}{|c|}{$\begin{array}{l}\text { WEB OF SCIENCE UAM, INGENIO UAM, COPUS UAM, GOOGLE ACADEMICO, } \\
\text { MICROSOFT ACADEMIC SEARCH, ERIC, REFSEEK, SCIENCE RESEARCH, WORLD } \\
\text { WIDE SCIENCE, SCIELO CERN, SCIENCE DIRECT, SCIENCE, ACM AND SPRINGER }\end{array}$} \\
\hline Search strategies & \multicolumn{2}{|c|}{$\begin{array}{l}\text { Two searches were run with combinations of different keywords: } \\
\text { - Search 1:"usability evaluation" and "down syndrome" } \\
\text { - Search 2: "cognitive disabilities" and "usability" } \\
\text { The results were successively refined considering: } \\
\text { 1. Year of publication: from } 2008 \text { to } 2014 \\
\text { 2. Relation of publications to technologies and computing } \\
\text { 3. Relation of usability to computer systems usability (Human-Computer Interaction - } \\
\text { HCI). }\end{array}$} \\
\hline
\end{tabular}

The literature review process (Figure 1) was composed of two searches: one used the terms "usability evaluation" and "down syndrome" and the other employed the terms "cognitive disabilities" and "usability". The preliminary list of papers $(621+415)$ was first pruned based on date of publication and the relevance of paper titles. This returned $58+57$ papers. The list was further pruned based on the relevance of the content of the abstracts. The result was a list of 98 papers $(43+55)$. These papers were read and analysed, and 11 papers were found to be of relevance to the topic of usability testing for people with DS. 
International Journal of Computer Science \& Information Technology (IJCSIT) Vol 8, No 3, June 2016

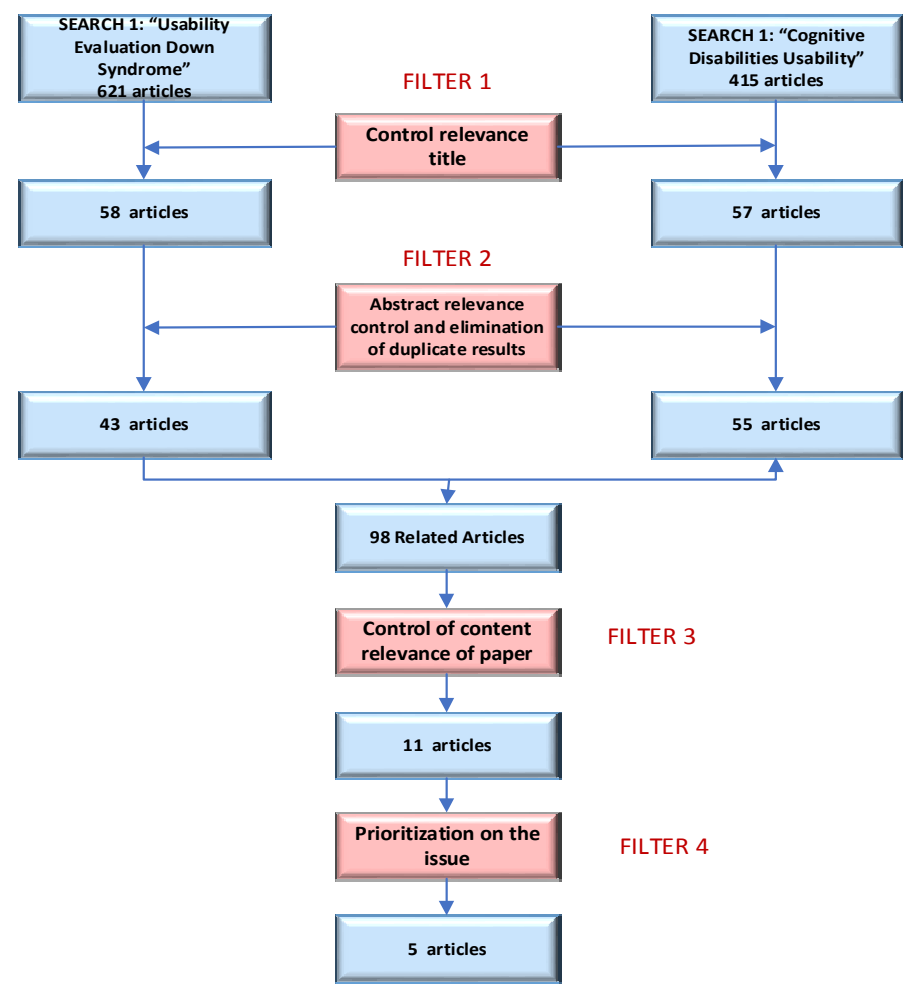

Figure 1 : Search refinement strategy flow diagram

The literature review process has consisted in two searches, one with terms "usability evaluation down syndrome" and the other with the terms "cognitive disabilities usability". The initial list of references was pruned in a first stage based on the relevance of their titles. Then a second pruning was made based on the relevance of the content of the abstracts. The result was a list of 98 papers. These papers have been read and analysed, then we had 11 articles.

These 11 papers were thoroughly analysed and sorted by priority (high, medium or low) depending on their contributions to the steps of the usability testing process (Table 3). The result was a list of five high-priority papers that are analysed in Section 4.

We applied the parameters in table 2 to determinate the level priority

Table 2: Information source inspection protocol

\begin{tabular}{|c|c|}
\hline \multicolumn{2}{|r|}{ Information source inspection protocol } \\
\hline Inspection rules: & $\begin{array}{l}\text { The order of inspection is as follows: } \\
\text { 1. Inspection of title } \\
\text { 2. Inspection of abstract } \\
\text { 3. If the information is relevant to the research topic, the content is inspected. }\end{array}$ \\
\hline Exclusion criteria: & $\begin{array}{l}\text { 1. Duplicate information } \\
\text { 2. Information unrelated to the research topic } \\
\text { 3. Outdated information. }\end{array}$ \\
\hline Inclusion criteria: & 1. Information relevant and related to the research topic \\
\hline
\end{tabular}

We applied a new filter giving a priority and an important level to the contribution research taking in count the approach of the investigation to the actual research. Finally we obtained result 5 papers have been useful to extract information about usability testing with participants. 
International Journal of Computer Science \& Information Technology (IJCSIT) Vol 8, No 3, June 2016

\subsection{SEARCHES}

\subsubsection{First Search: Usability \& Evaluation \& Down Syndrome}

The search is performed in 15 databases, the filters are different for each repository because each search engine has different filtering options.

- WEB OF SCIENCE: The first filter is the year since 2008 to 2015. We found 10 documents. We analysed taking in count the relevance and the relationship with research topic. We selected 5 main documents.

- INGENIO: We wrote the sentences without filters and got 3341 results. We applied a second filter in the tool with the topic Informatics and Computing. We got 338 results. The second filter is the date between 2010 hasta October 2015 getting 133 results. The third filter was analyze the titles and read the abstracts getting 9 documents.

- SCOPUS: The first filter is the year since 2008 until 2015 getting 13 researches then we removed the duplicate documents. We analysed taking in count the relevance and the relationship with research topic. We select 2 main documents.

- GOOGLE ACADEMICO: We wrote the sentences without filters and got 464 results. We filtered the year since 208 until 2015, we had 305 articles. We applied a new filter Usability and human computer interaction and we got 191 results. We applied another filter with "Down Syndrome" then we had 50 publications. We analysed taking in count the relevance, abstract, title and the relationship with research topic. After that we had 5 documents.

- $\quad$ MICROSOFT ACADEMIC SEARCH: We wrote the sentences without filters and got 25 results. We filtered with Computer Science getting 9 publications. We analysed taking in count the relevance, abstract, title and the relationship with research topic. After that we had 2 documents.

- ERIC: We analysed taking in count the relevance, abstract, title and the relationship with research topic. After that we had 1 document.

- REFSEEK: The search "Usability Evaluation" and Down Syndrome retorna 702 resultados, se añade al filtro la palabra "HCI" con lo que se tiene 461resultados. Se selecciona Tipo Publicación = Documento y quedan 2 elementos a ser tomados.

- SCIENCE RESEARCH : La sentencia "Usability Evaluation" And "Down Syndrome" con el filtro Año entre 2008 Y 2014 retorna 77 resultados. Se añade la palabra "HCI" y se obtiene 31 resultados. Se eliminan repetidos y se seleccionan los 2 artículos más relevantes.

- WORLD WIDE SCIENC La búsqueda: "Usability Evaluation" And "Down Syndrome" da 317 resultados. Se añade el filtro de año entre 2008 Y 2014 retorna 55 resultados se filtra nuevamente con la palabra "HCI" y se obtienen 12 resultados. De estos, se analiza, se descarta repetidos y se toma 1.

- SCIELO: La búsqueda "Usability" And Down Syndrome retorna 3 resultados. Se mejora la sentencia "Usability Evaluation" And Down Syndrome y se obtiene 1 resultado útil.

- CERN: La Búsqueda "Usability" And Down Syndrome retorna 3 resultados, se detalla la búsqueda "Usability Evaluation" And Down Syndrome y se obtiene 1 resultado relacionado.

- SCIENCE DIRECT: La primera sentencia genera 807 resultados con el patrón general. Se procede con el filtro por: Research in Developmental Disabilities (16) OR filtro por: Computers \& Education (15). or filtro por: International Journal of Human-Computer Studies (14). Se obtiene un total de 45 resultados y por relevancia se seleccionan 11.

- SCIENCE; "Usability" And "Evaluation" And "Down Syndrome" and Filtro Por HCI genera 174 resultados se añade filtro por science y devuelve 29 resultados, se ingresa 
un nuevo filtro por Technology se tienen 10 resultados Se eliminan repetidos y se selecciona un único artículo relevante.

- ACM: Devuelve 204 resultados de los cuales se revisa todos los títulos, abstracts, se descarta repetidos y se toman los 5 documentos relacionados

- SPRINGER: Da 731 resultados . Con el filtro por Computer Science retorna 259 resultados.Un nuevo filtro por HCI genera 112 resultados. Se añade un filtro por fechas del 2008 a 2014 obtenemos 88 resultados . Los mismos son analizados por título, abstract y se descarta repetidos y se seleccionan los 8 más relacionados con el tema.

\subsubsection{Segunda búsqueda: Cognitive Disabilities Usability}

Se realiza la búsqueda en 15 bases de datos, los filtros son diferentes para cada repositorio ya que cada el motor de búsqueda presenta diferentes opciones de filtrado.

- WEB OF SCIENCE: Inicialemte se obtienen 52 artículos, se filtran por ciencia y tecnología y se obtienen 47 . Se analizan los títulos y abstracts y se descartan repetidos y se toman 8 de los cuales se seleccionan 5 luego de su lectura de acuerdo a su relación y relevancia.

- INGENIO: Retorna 5.781 artículos en la primera búsqueda de los cuales se filtra por años de publicación del 2008 al $2014=3.807$. Adicionalmente se usan criterios para discriminar el tipo de usabilidad para que sea la relacionada con human computer interaction $=37$ artículos. Se procede con la revisión de títulos y se seleccionan 37 y por relevancia se selecciona 8 de los cuales 3 están relacionados.

- SCOPUS 125 documentos totales, filtrados por años del 2008 al 2014 se tiene como resultado 92 documentos, Computer Science $=92$ documentos. Se procede con la revisión de títulos y se selecciona 20. Luego de la revisión de los resúmenes se escogen 8 de los cuales hay tres repetidos o incluidos en otras búsquedas. Por lo tanto tomamos 4.

- GOOGLE ACADEMICO: Desde 2008 hasta 2014, "Evaluation Usability" And "Cognitive Disability" Or "Syndrome Down" Or "HCI"= 31 resultados. Se procede a revisar el contenido de 31 y se seleccionan los 2 relacionados.

- MICROSOFT ACADEMIC SEARCH EVALUATION: La búsqueda Usability "Cognitive Disabilities" Or "Syndrome Down" Or "Hci" And "Computer Science" = 9articulos. Los artículos tiene fecha anterior al 2008 por lo que se descartan y se toma 1.

- ERIC "Evaluation Usability " And "Cognitive Disabilities" Or "Syndrome Down" Or "Hci" And Año De Publicacion del 2008 al 2014 .Se filtra por Higher Education = 4319. Se filtra por disabilities $=595, \quad$ Disability $\&$ Society $=11$ resultados. Se analizan los 11 documentos por título, abstract, se descartan los repetidos y se selecciona 1.

- SCIENCE RESEARCH: Retorna 1821 artículos totales. Filtrado por año del 2008 al $2014 \&$ Computer and Tecnology \&Defense Tecnology,$=20$. Se filtra por research $=$ 25. Se revisan los 25 titulos y se toma 2 con tema relacionado, se revisan los dos resúmenes quedando solo 1 como relacionado y relevante.

- WORLD WIDE SCIENCE ORG: Retorna 493 artículos totales, se filtra por Research = 57. La revisión de títulos, abstracts y descartando repetidos concluye seleccionando 1

- SCIELO; Retorna 6 artículos de los cuales no existen relacionados no repetidos.

- CERN: Retorna 6 artículos de los cuales eliminando repetidos y no relacionados se selecciona 1.

- SCIENCE DIRECT "Evaluation Usability "And "Cognitive Disability" Or "Down Syndrome" Or "Hci" = 60 resultados. Se filtra por año desde 2008 a $2014=32$ resultados. La revisión de títulos, contenidos y descartando repetidos concluye seleccionando 2 artículos.

- SCIENCE GOV: Retorna 837 artículos. Accessibility $=61$, de los cuales se filtra por categoría People with Disabilities $=15$ Se analizan los artículos por revisión de títulos, contenidos y descartando repetidos, se seleccionan 2. 
- ACM: retorna 1123 totales se filtra por año 2008 a $2014=794$. Se filtra por el contexto $\mathrm{HCI}=544$ y "Down Syndrome" $=38$. Se procede con la revisión de 38 artículos por revisión de títulos, contenidos y descartando repetidos de los cuales se seleccionan 3.

- SPRINGER: retorna 2170 artículos totales Se filtra por Computer Scince $=1509$, HCI $=1097$, Entre 2008 y 2014 son 787, Cognitive Disabilities And Usability 106 documentos que se realiza la revisión de títulos, contenidos y descartando repetidos de los cuales se toman 19 .

- REFSEEK: Retorna 135,000 artículos totales, Se aplica el filtro por "Cognitive Disability" And "Usability" $=2,020$. Se filtra por HCI $=20$. Luego de la revisión de títulos, contenidos y descartando repetidos Se seleccionan 4 pero son de años anteriores a 2006 por tanto estos se descartan.

\subsubsection{Análisis de resultados por Año}

La tabla 2 se muestra la clasificación de los resultados obtenidos con respecto al año de publicación. En el marco de tiempo seleccionado (del 2008 al 2014) se puede apreciar un crecimiento casi constante del 2008 al 2012 en donde se alcanza un pico. El decrecimiento en el 2014 podría deberse a que aún no se ha terminado el año por lo cual no se podría considerar que es una temática que tiende a bajar su nivel de investigaciones.

Tabla No. 2: Número de Artículos por año de Publicación

\begin{tabular}{|c|r|r|r|}
\hline AÑO & BUSQUEDA 1 & BUSQUEDA 2 & TOTAL \\
\hline 2008 & 0 & 6 & 6 \\
\hline 2009 & 8 & 3 & 11 \\
\hline 2010 & 10 & 6 & 16 \\
\hline 2011 & 7 & 8 & 15 \\
\hline 2012 & 10 & 10 & 20 \\
\hline 2013 & 5 & 13 & 18 \\
\hline 2014 & 3 & 9 & 12 \\
\hline TOTAL: & 43 & 55 & 98 \\
& & & \\
\hline
\end{tabular}

Table 3 : Summary and classification of preselected papers

\begin{tabular}{|l|c|l|}
\hline \multicolumn{1}{|c|}{ DOCUMENT } & $\begin{array}{c}\text { PRIORIT } \\
\text { Y }\end{array}$ & \multicolumn{1}{c|}{ SUMMARY } \\
\hline $\begin{array}{l}\text { A method to evaluate } \\
\text { disabled user interaction: a } \\
\text { case study with Down } \\
\text { syndrome children [4]. 2013. }\end{array}$ & High & $\begin{array}{l}\text { This study designed by [4] evaluated four children aged between } \\
6 \text { and 12 years with DS and analyses the development of the } \\
\text { coding scheme based on the detailed video analysis method } \\
\text { (DEVAN) to observe the interaction of the children with DS. } \\
\text { Also applies IQ evaluation and use JECRIPE tool. The test plan } \\
\text { is to deliver the application to the children, observe and film. No } \\
\text { pilot test was run. Finally, the workshop was held and the results } \\
\text { for each child evaluated on average for 45 minutes for all } \\
\text { process were analysed. }\end{array}$ \\
\hline $\begin{array}{l}\text { A Usability Evaluation of } \\
\text { Workplace-Related Tasks on } \\
\text { a Multi-Touch Tablet } \\
\text { Computer by Adults with } \\
\text { Down Syndrome [9]. 2012. }\end{array}$ & High & $\begin{array}{l}\text { Two pilot sessions are run: administer demographic } \\
\text { questionnaire to participants and validate participant recruitment } \\
\text { criteria. Participants were asked to perform five different } \\
\text { categories of tasks on an iPad (social networking, electronic } \\
\text { mail, scheduling / planning, price comparison and basic text } \\
\text { input / note taking). No formal data collection or methodology } \\
\text { was applied. Use patterns were observed. They were then used to } \\
\text { write a list of tasks and develop a methodology. Participants } \\
\text { were reevaluated during the second session, and this information }\end{array}$ \\
\hline
\end{tabular}




\begin{tabular}{|c|c|c|}
\hline & & was used to rewrite the list of tasks. \\
\hline $\begin{array}{l}\text { Designing Usability } \\
\text { Evaluation Methodology } \\
\text { Framework of Augmented } \\
\text { Reality Basic Reading } \\
\text { Courseware (AR BACA } \\
\text { SindD) for Down Syndrome } \\
\text { Learner [10]. 2011. }\end{array}$ & High & $\begin{array}{l}\text { This paper proposes a usability evaluation framework for an } \\
\text { augmented reality framework for learners with DS. To do this, } \\
\text { three to five expert interface design and learning content } \\
\text { evaluators were recruited. They analysed } 10 \text { adults with DS to } \\
\text { evaluate how proficient they were at using multi-touch tablets } \\
\text { for job-related tasks. The evaluation was divided into two } \\
\text { phases: an acceptance testing phase including formative } \\
\text { assessment and a usability phase including either a formative } \\
\text { phase with an iterative development cycle or a summative phase } \\
\text { where testing is conducted with a large number of users. The } \\
\text { goal was to identify strengths and weaknesses [10]. }\end{array}$ \\
\hline $\begin{array}{l}\text { The complementary role of } \\
\text { two evaluation methods in } \\
\text { the usability and accessibility } \\
\text { evaluation of a non-standard } \\
\text { system [11]. } 2010 .\end{array}$ & High & $\begin{array}{l}\text { [11] worked with five usability and accessibility experts and six } \\
\text { learners to evaluate a literacy system in Africa. It was evaluated } \\
\text { using the heuristic method and a usability field study. First a } \\
\text { pilot study was run to gain an idea of how the applications work. } \\
\text { The pilot study activities were: run the evaluation and draft a } \\
\text { report of the compiled evaluation for submission to the } \\
\text { immediate evaluator. }\end{array}$ \\
\hline $\begin{array}{l}\text { Usability Evaluation of } \\
\text { Multimedia Courseware } \\
\text { (MEL-SindD) [12]. 2009. }\end{array}$ & High & $\begin{array}{l}\text { This paper discusses the usability assessment of the courseware, } \\
\text { the methods used for the evaluation, as well as suitable } \\
\text { approaches that can be deployed to evaluate the courseware } \\
\text { effectiveness for disabled children. The evaluation was divided } \\
\text { into three phases: PHASE } 1 \text {. Identify user needs, PHASE } 2 \text {. } \\
\text { Evaluate usability with the participation of } 11 \text { students with DS, } \\
\text { and PHASE 3. Send the data collected by the researcher to the } \\
\text { specialist teachers and parents of the recruited children with DS. }\end{array}$ \\
\hline $\begin{array}{l}\text { Usability of the } \\
\text { SAFEWAY2SCHOOL } \\
\text { system in children with } \\
\text { cognitive disabilities]. [13] }\end{array}$ & Low & $\begin{array}{l}\text { Fourteen children with DS and a control group of } 23 \text { children } \\
\text { without disabilities participated in the study conducted by } \\
\text { (Falkmer et al., 2014) which involved evaluating a system for } \\
\text { improving safe school transport for children. }\end{array}$ \\
\hline $\begin{array}{l}\text { Validating WCAG versions } \\
1.0 \text { and } 2.0 \text { through usability } \\
\text { testing with dis-abled users } \\
{[14] .2012 .}\end{array}$ & Low & $\begin{array}{l}\text { This paper reports a study that empirically validated the } \\
\text { usefulness of using WCAG as a heuristic for website } \\
\text { accessibility. }\end{array}$ \\
\hline $\begin{array}{l}\text { Usability remote evaluation: } \\
\text { METBA system [15]. } 2012 .\end{array}$ & Low & $\begin{array}{l}\text { This paper reports a solution (METBA) for managing the } \\
\text { information related to the evaluation of human behavioural } \\
\text { observation. The system is used to register and manage the } \\
\text { information derived from remote usability evaluation and } \\
\text { complements the methodology commonly used in this research } \\
\text { area. }\end{array}$ \\
\hline $\begin{array}{l}\text { Computer Usage by Children } \\
\text { with Down Syndrome: } \\
\text { Challenges and Future } \\
\text { Research [16]. } 2010\end{array}$ & Low & $\begin{array}{l}\text { This paper reports the text responses collected in the survey and } \\
\text { is intended as a step towards understanding the difficulties } \\
\text { experienced by children with DS when using computers. }\end{array}$ \\
\hline $\begin{array}{l}\text { A multi-method, user- } \\
\text { centered evaluation of } \\
\text { accessibility for persons with } \\
\text { disabilities [17]. } 2009 .\end{array}$ & Low & $\begin{array}{l}\text { The Study have assessed the accessibility of web site from } \\
\text { federal e-government. The conclusion is that web sites should be } \\
\text { accessible to persons with disabilities. }\end{array}$ \\
\hline
\end{tabular}


International Journal of Computer Science \& Information Technology (IJCSIT) Vol 8, No 3, June 2016

\begin{tabular}{|l|l|l|}
\hline $\begin{array}{l}\text { Computer Usage by Young } \\
\text { Individuals with Down } \\
\text { Syndrome: An Exploratory } \\
\text { Study [18]. 2008. }\end{array}$ & Low & $\begin{array}{l}\text { This paper discusses the results of an online survey that } \\
\text { investigates how children and young adults with DS use } \\
\text { computers and computer-related devices. }\end{array}$ \\
\hline
\end{tabular}

Las partes más relevantes en relación al tema propuesto de los diferentes papers que han sido seleccionados, son descritos a continuación:

A method to evaluate disabled user interaction: a case study with down syndrome children, el autor usa el DEVAN Method for children with Down syndrome. Además el aporte del estudio concluye que los niños con Síndrome de Down tienen dificultad para verbalizar sus sentimientos y pensamientos, por esta razón fue eliminada la necesidad de la verbalización de la definición de las indicacio-nes. [8]

The complementary role of two evaluation methods in the usability and accessi-bility evaluation of a non-standard system, propone diferentes opciones de Eva-luación como completar el método de evaluación heurística se debe completar con estudio de campo. Usa también una tabla de resumen de Métodos de Evalua-ción de Usabilidad. Concluye que el método de evaluación heurística es flexible y puede ser utilizado para la evaluación formativa o sumativa, siempre se usan criterios de evaluación apropiados. Recomienda también que para seleccionar métodos de evaluación depende de factores, como la etapa del ciclo de vida de desarrollo en el que la evaluación se lleva a cabo (formativa o sumativa), si la evaluación debe llevarse a cabo en un ambiente controlado o entorno natural y la disponibilidad de los recursos [6]

Designing Usability Evaluation Methodology Framework of Augmented Reality Basic Reading Courseware (AR BACA SindD) for Down Syn-drome Lear-ner.presenta una tabla de resumen de Métodos de Evaluación de Usabilidad. Usa diferentes métodos como heuristic evaluation, pluralistic walkthrough, cognitive walk-through, and graphical jog- through. Divide la evaluación en 2 : Test de Aceptabilidad y Test de Usabilidad de la Aplicación Abarca SD. [3]

A Usability Evaluation of Workplace-Related Tasks on a Multi-Touch Tablet Computer by Adults with Down Syndrome. Realiza inicialmente un Ccestionario Demofráfico con parámetros como género, edad, educación, empleo, experiencia en Computación, etc. Describe también algunos Tips para desarrollar una evalua-ción de Usabilidad con personas con Síndrome de Down. Los adultos con sín-drome de Down son capaces de utilizar eficazmente los dispositivos multi-touch para las tareas relacionadas con el lugar de trabajo, (b) una formación informáti-ca institucionalizada parece afectar participante rendimiento, y (c) la usabilidad contraseña sigue siendo un reto para las personas con síndrome de Down. Sugiere entregar Tareas escritas en Papel. Pedir a usuarios que califiquen la dificultad de las tareas utilizando una escala Likert de 5 puntos. Hacer grafica la escala para el taller. Concluye también que las habilidades visuales motoras, habilidades de procesamiento visual y habilidades de memoria visual son caminos fuertes para el aprendizaje de las personas con síndrome de Down, mientras que el procesamiento auditivo y memoria auditiva se encuentran para ser canales relativamente más débiles para el aprendizaje. En cuanto al proceso de Evaluación primero realiza un Piloto para la observación de patrones de uso, luego redacta y desa-rrollar la metodología. En el segundo Piloto modifica la Metodología. Usa técnica Warm-up task que es el calentamiento de participantes. Añadió una pregunta sobre previo uso de computadores. Los principales problemas encontrados fue-ron la entrada de texto en teclados virtuales, problema en contraseñas, problemas Menú desplegables. [36]

Usability Evaluation of Multimedia Courseware (MEL-SindD). - Realiza una Tabla Summary of Usability evaluation methods. Usa los métodos de observa-ción, entrevista y la realización de una evaluación de expertos del material di-dáctico. En el proceso de Evaluación usa diferentes tareas como: entrevista con pediatra, entrevistas con los maestros para saber más sobre los 
escenarios de enseñanza y aprendizaje, entrevista con alumno con SD preguntas simples claras y corta. Como recomendación general, el investigador tiene que prestar una atención especial para obtener la confianza entre los usuarios, y conocerlos antes de la sesión de evaluación.[9]

\section{LITERATURE REVIEW RESULTS}

We analysed the five selected papers with regard to their contributions to each of the usability testing process Figure 2. A user-centred design process is applied to build products and systems with a satisfactory level of usability (Standard). As part of this process, planning, context of use analysis, interactive system design and evaluation tasks are carried out iteratively. A key step is usability evaluation. There are several methods for evaluating how usable a product or system is: heuristic or guideline evaluation, usability testing and follow-up studies of installed systems (Adebesin and Gelderblom). The most common method is usability testing, which involves testing prototypes with real users (Diah et al.). Participating users are set a number of tasks that they have to perform using a prototype or a full system. Data on the effectiveness, efficiency and satisfaction of users are collected during testing. Generally, the usability process is divided into the following steps:

1. Recruit participants after determining the population group of interest and the required number of participants.

2. Establish the tasks that are to be used in the usability tests.

3. Write the instructions that participants will be given to perform the usability test.

4. Define the test plan, which is a protocol stating activities like welcome, pre-test interview, observed task performance by user, satisfaction questionnaire, personal interview to gather qualitative information, etc.

5. Run the pilot test to analyse whether the process works to plan.

6. Refine the test plan after analysing the results of the pilot tests.

7. Run the test session.

8. Analyse the collected objective (times, number of errors, etc.) and subjective (satisfaction questionnaires) data.

9. Report results to the development team or management. 
International Journal of Computer Science \& Information Technology (IJCSIT) Vol 8, No 3, June 2016

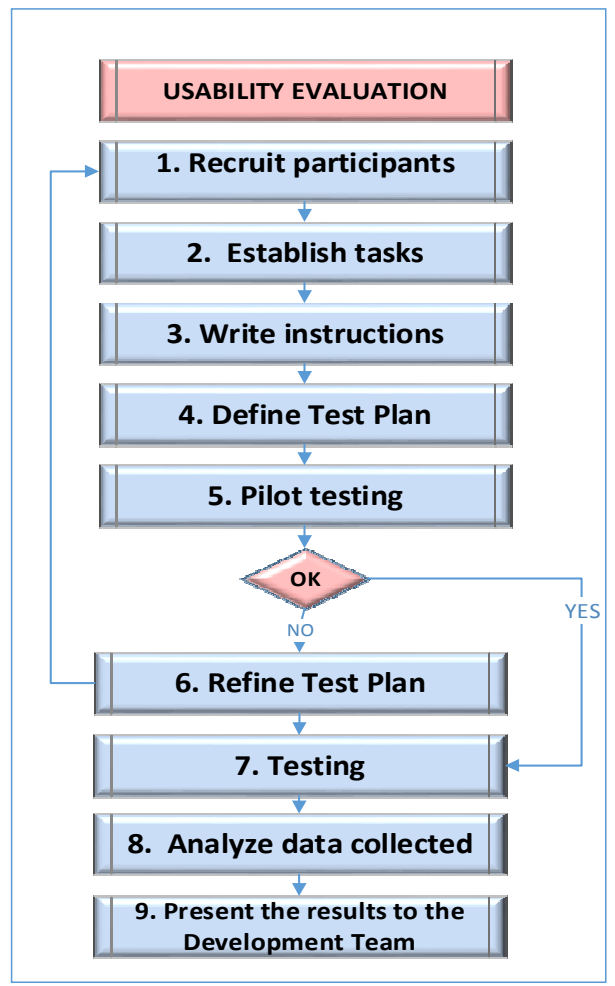

Figure 2: Usability Testing Process

The literature review process described in Section 3 focused on identifying papers that report a usability test with people with Down syndrome and on retrieving the key information that they provide on each of these nine steps. The Table: 4 , show the detailed contribution of each author in each phase of the usability process.

Table 4: Part of the analysis of the research on usability testing for people with DS

\begin{tabular}{|c|c|}
\hline $\begin{array}{l}\text { 1. Recruit } \\
\text { participants }\end{array}$ & $\begin{array}{l}\text { From the analysis of the research with regard to the recruitment of participants, we find that [4] } \\
\text { take four children aged from } 6 \text { to } 12 \text { years with DS, [11] use five usability experts and six } \\
\text { learners, [10] use from three to five interface design and learning content experts, and [19] work } \\
\text { with two paediatricians, primary school teachers and } 11 \text { children with DS. This illustrates the } \\
\text { importance of working with on average } 10 \text { paediatricians, interface and learning content } \\
\text { evaluators and people with DS. }\end{array}$ \\
\hline $\begin{array}{l}\text { 2. Establish } \\
\text { tasks }\end{array}$ & $\begin{array}{l}\text { [4] holds a 30-minute training session, takes } 20 \text {-minute videos per child and uses the DEVAN } \\
\text { method to work directly with children with DS. On the other hand, [11] evaluate a literacy portal } \\
\text { in Africa using the following tasks: submission of evaluation criteria, submission of document } \\
\text { stating procedure to be followed, submission of document on interfaces and applications for } \\
\text { evaluation, signature of anonymity and confidentiality forms. In the research by [11], the experts } \\
\text { identify critical usability problems in the early stages of the development cycle and divide the } \\
\text { evaluation into two phases: acceptance testing and usability. [12] divide the tasks used in the } \\
\text { evaluation into several phases: PHASE 1. Identify user needs, iteratively engage students in } \\
\text { testing, and collect data from teachers and parents of students with DS, PHASE 2. Conduct the } \\
\text { usability evaluation, and PHASE 3. Collect the data from specialist teachers and parents and hold } \\
\text { the scheduled interviews. The activities specified by [9] are validate the criteria for recruiting } \\
\text { participants, like computer experience. }\end{array}$ \\
\hline $\begin{array}{l}\text { 3. Write } \\
\text { instructions }\end{array}$ & $\begin{array}{l}\text { [12] describe the instructions for identifying the needs of users, which are collect data, interview } \\
\text { students' paediatrician and primary school teachers, interact socially with students; identify the } \\
\text { learning needs. Understand the problems through conversations with parents; interview } \\
\text { specialists, teachers and parents as informers on the background of students and the research. }\end{array}$ \\
\hline
\end{tabular}




\begin{tabular}{|l|l|}
\hline $\begin{array}{l}\text { 5. Pilot } \\
\text { testing }\end{array}$ & $\begin{array}{l}\text { [11] conduct a pilot test aimed at understanding how applications work. [9] believe formal data } \\
\text { collection to be important for the pilot test. This should be followed by a second session during } \\
\text { which they suggest modifying the list of tasks, adding a warm-up task, giving tips on how to } \\
\text { move forward and encouraging thinking aloud. }\end{array}$ \\
\hline 6. Testing & $\begin{array}{l}\text { [12] collect the data iteratively from people with DS in Phase 1. Another aim is identify the } \\
\text { suitability of the teaching material for the learning problems that students are set. [11] describe } \\
\text { the testing steps: execute evaluation, write report, submit report to immediate evaluator, okay } \\
\text { report, and compile evaluation reports. }\end{array}$ \\
\hline
\end{tabular}

After the exhaustive analysis we wrote the contributions of each paper Table 5 sets out the information regarding which papers provide key information for each of the steps.

Table 5: Contributions of usability testing papers

\begin{tabular}{|l|c|c|c|c|c|}
\hline Paper & $\begin{array}{c}\text { 1. Recruit } \\
\text { participants }\end{array}$ & $\begin{array}{c}\text { 2. Establish } \\
\text { tasks }\end{array}$ & $\begin{array}{c}\text { 3. Write } \\
\text { instructions }\end{array}$ & $\begin{array}{c}\text { 5. Pilot } \\
\text { testing }\end{array}$ & 7. Testing \\
\hline$[4] 2013$. & $\mathrm{X}$ & $\mathrm{X}$ & & & \\
\hline$[11] 2010$. & $\mathrm{X}$ & $\mathrm{X}$ & & $\mathrm{X}$ & $\mathrm{X}$ \\
\hline$[10] 2011$. & $\mathrm{X}$ & $\mathrm{X}$ & & & \\
\hline$[9] 2012$. & & $\mathrm{X}$ & & $\mathrm{X}$ & \\
\hline$[12] .2009$. & $\mathrm{X}$ & $\mathrm{X}$ & $\mathrm{X}$ & & $\mathrm{X}$ \\
\hline
\end{tabular}

Note that there are contributions regarding five of the nine usability testing steps: recruit participants (1), establish tasks (2), write instructions (3), pilot testing (5) and testing (7). Table 5 contains the key contributions regarding each of the steps.

Briefly, the retrieved information is as follows. As regards the instructions on tasks, there is very little information. Additionally, the test plan that can be enacted for the population group of interest is not clearly defined. Even though pilot testing greatly improves the second round of testing, pilot tests are seldom used, and the papers fail to establish the format or steps to be taken. As regards testing, they only describe the activities performed without any specific specifications for participants with DS. Therefore, we can conclude that the different papers contain no recommendations as regards the addressed research topic. Table 5 details the activities to be performed to achieve the specific goal of each piece of research but not a general-purpose method proposed by the authors that is applicable across the board.

\section{CONCLUSIONS AND FUTURE WORK}

The document analysis reveals that usability has been well researched. As regards usability evaluation, there are many proposals and methodologies. However, we have not found any significant efforts considering mobile applications and people with DS. On this ground, there is a patent need to state guidelines on all the steps to be taken to test the usability of applications for mobile devices for people with DS.

We have started to work on this line of research. To do this, we will take into account some of the interesting contributions identified in the analysed papers. Specifically, children with DS find it hard to express their feelings and thoughts. On this ground, it is recommended that they should not be asked to verbalize their suggestions [4]. A pre-test demographic questionnaire is recommended [10]. Different methods, including heuristic evaluation, pluralistic walkthrough, cognitive walkthrough, and graphical jog through, can be used, which should, additionally, be rounded out with a field study. Adults with DS are able to effectively use multi-touch devices for 
job-related tasks, although password use is still a usability challenge for people with DS. A fivepoint Likert scale can be used if users are required to rate task difficulty. People with DS have strong visual motor, visual processing and visual memory learning skills, whereas auditory processing and auditory memory are found to be relatively weaker learning channels. The key problems identified were text input using virtual keyboards, problems with passwords and problems with pull-down menus [9]. Researchers should make sure that they gain the trust of and get acquainted with users before the evaluation session [12].

On the other hand, as the identified information is incomplete, we are conducting experimental studies in order to round out the guidelines using the knowledge acquired directly from contact with people with DS. For example, we are holding workshops for both children and adults with DS in order to identify their needs with respect to the use of mobile devices with a basic gesturebased application, including touch, double touch, drag, rotation, press, scale down and scale up. We have found that the 108 participants have special needs and the general usability testing procedures do not work well.

Mobile computing has a very promising future with a view to improving the life of people with DS, provided that the developed solutions meet the needs of these people. Accordingly, the proposed research on usability testing with people with DS is an opportunity to improve the inclusion of this population group which is at risk of exclusion from technological development.

\section{ACKNOWLEDGEMENTS}

This work was also supported by a pre-doctoral scholarship given by the SENESCYT (Secretaria

Nacional de Educación Superior, Ciencia y Tecnología e Innovación) of the government of Ecuador (N0. 381 -2012) to Doris Cáliz.

\section{REFERENCES}

[1] E. L. Zeilinger, K. a M. Stiehl, and G. Weber, "A systematic review on assessment instruments for dementia in persons with intellectual disabilities," Res. Dev. Disabil., vol. 34, no. 11, pp. 39623977, 2013.

[2] R. Lob Yussof and H. Badioze Zaman, "Scaffolding in early reading activities for Down syndrome," Lect. Notes Comput. Sci. (including Subser. Lect. Notes Artif. Intell. Lect. Notes Bioinformatics), vol. 7067 LNCS, no. PART 2, pp. 180-192, 2011.

[3] A. C. Jones, E. Scanlon, and G. Clough, "Computers \& Education Mobile learning : Two case studies of supporting inquiry learning in informal and semiformal settings," Comput. Educ., vol. 61, pp. 21-32, 2013.

[4] I. Macedo and D. G. Trevisan, "A Method to Evaluate Disabled User Interaction : A Case Study with Down Syndrome Children," Univers. Access Human-Computer Interact. Des. Methods, Tools, Interact. Tech. eInclusion, pp. 50-58, 2013.

[5] I. Standard, "DRAFT INTERNATIONAL STANDARD ISO / FDIS,” vol. 2009, 2010.

[6] F. Adebesin and P. H. Gelderblom, "Technical Report Usability and Accessibility Evaluation of the Digital Doorway."

[7] N. M. Diah, M. Ismail, S. Ahmad, and M. K. M. Dahari, "Usability testing for educational computer game using observation method,” Proc. - 2010 Int. Conf. Inf. Retr. Knowl. Manag. Explor. Invis. World, CAMP'10, pp. 157-161, 2010.

[8] J. W. Barbosa Chacón, J. C. Barbosa Herrera, and M. Rodrígue Villabona, "Revisión y análisis documental para estado del arte: Una propuesta metodológica desde el contexto de la sistematización de experiencias educativas," Investig. Bibl., vol. 27, no. 61, pp. 83-105, 2013.

[9] L. Kumin and J. Lazar, “A Usability Evaluation of Workplace-Related Tasks on a Multi-Touch Tablet Computer by Adults with Down Syndrome,” J. Usability ..., vol. 7, no. 4, pp. 118-142, 2012.

[10] R. Ramli and H. B. Zaman, "Designing usability evaluation methodology framework of Augmented Reality basic reading courseware (AR BACA SindD) for Down Syndrome learner," Proc. 2011 Int. Conf. Electr. Eng. Informatics, ICEEI 2011, no. July, 2011. 
International Journal of Computer Science \& Information Technology (IJCSIT) Vol 8, No 3, June 2016

[11] F. Adebesin, P. Kotzé, and H. Gelderblom, "The complementary role of two evaluation methods in the usability and accessibility evaluation of a non-standard system," Proc. 2010 Annu. Res. Conf. South African Inst. Comput. Sci. Inf. Technol. - SAICSIT '10, pp. 1-11, 2010.

[12] R. L. Yussof and H. Badioze Zaman, "Usability evaluation of multimedia courseware (MELSindD)," Lect. Notes Comput. Sci. (including Subser. Lect. Notes Artif. Intell. Lect. Notes Bioinformatics), vol. 5857 LNCS, pp. 337-343, 2009.

[13] S. K. D. Mello, S. D. Craig, B. Gholson, S. Franklin, R. Picard, and A. C. Graesser, "Integrating Affect Sensors in an Intelligent Tutoring System," Affect. Interact. Comput. Affect. Loop Work. 2005 Int. Conf. Intell. User Interfaces, pp. 7-13, 2005.

[14] D. Rømen and D. Svanæs, "Validating WCAG versions 1.0 and 2.0 through usability testing with disabled users," Univers. Access Inf. Soc., vol. 11, no. 4, pp. 375-385, 2012.

[15] F. Alcantud, J. Coret, E. Jiménez, S. Márquez, F. Moreno, and J. Pérez, "Usability remote evaluation: METBA system,” 2012 15th Int. Conf. Interact. Collab. Learn. ICL 2012, 2012.

[16] J. Feng, J. Lazar, and L. Kumin, "Computer Usage by Children with Down Syndrome : Challenges and Future Research," Computer (Long. Beach. Calif)., vol. 2, no. 3, p. 13, 2010.

[17] P. T. Jaeger, "Assessing Section 508 compliance on federal e-government Web sites: A multimethod, user-centered evaluation of accessibility for persons with disabilities," Gov. Inf. Q., vol. 23, no. 2, pp. 169-190, 2006.

[18] J. Feng, J. Lazar, L. Kumin, and a Ozok, "Computer Usage by Young Individuals with Down Syndrome: An Exploratory Study,” Proc. 10th Int. ACM SIGACCESS Conf. Comput. Access., pp. 35-42, 2008.

[19] R. L. Yussof and T. N. S. T. Paris, "Reading Activities Using the Scaffolding in MEL-SindD for Down Syndrome Children," Procedia - Soc. Behav. Sci., vol. 35, no. December 2011, pp. 121-128, 2012.

\section{Authors}

Ing. MSc. Doris Cruz Caliz Ramos.

- Computer Sciences Engineering

- Master in Management of Information Technology and Communications National Polytechnic School Ecuador. 2008 - 2012

- International Leadership Training. Germany. 2011 - 2012

- PHD Student in Polytechnic School Madrid. 2013- 2017

- Academic Visitor in Middlesex University London. 2015 - 2016

\section{Doctor. Loic Antonio Martinez Normand}

- Professor Department ETSIINF, DLSIIS, Madrid Polytechnic University. 2008 - Today.

- Researcher in Group Investigation on Technology Informatics and Communications: CETTICO.

- President Sidar Foundation. 2002 - Today

Ing.MSc. Richarth Harold Caliz Ramos.

- Master in Management of Information Technology and Communications MSc, final mark: cum laude. National Polytechnic School (EPN), Quito, Ecuador (Fall 2008Winter 2010)

- Telecommunications and Electronics Engineering, final mark: cum laude. National Polytechnic School (EPN), Quito, Ecuador (Fall 1995-Winter 2002)

\section{Ing. MSc. Carlos Miguel Terán Villamarín}

- Computer Sciences Engineering

- Master in Management of Information Technology and Communications National Polytechnic School Ecuador. 2008 - 2012

- Vice-president Technology Department in COBISCORP. S.A
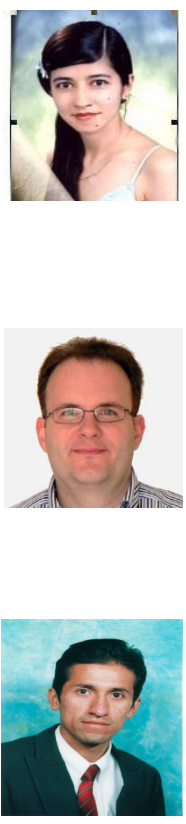
International Journal of Computer Science \& Information Technology (IJCSIT) Vol 8, No 3, June 2016

\section{Xavier Alamán Roldán}

- Professor Autonomous University Madrid Computer Sciences and Artificial Intelligence. 1993 - Today

- Doctor CC. Physics UCM in 1993

- M.Sc. on Artificial Intelligence (UCLA).

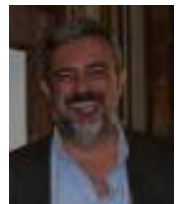

